\title{
Intravenous administration of thiomolybdate for the prevention and treatment of chronic copper poisoning in sheep
}

\author{
By S. R. GOONERATNE, J. MCC. HOWELL AND J. M. GAWTHORNE \\ Division of Veterinary' Biology, School of Veterinary Studies, Murdoch University, \\ Murdoch, Western Australia 6150, Australia
}

(Received I April 1980-Accepted 3 June 1981)

1. Twenty-six sheep were used in experiments designed to test the effectiveness of ammonium tetrathiomolybdate in the prevention and treatment of chronic copper poisoning.

2. Intravenous injections of $130 \mathrm{mg}$ ammonium tetrathiomolybdate twice weekly $(a)$ prevented the occurrence of haemolytic crisis in sheep repeatedly dosed with copper sulphate and $(b)$ minimized tissue damage and prevented further haemolytic crisis when छiven to sheep already in haemolysis.

3. Thiomolybdate prevented zxcessive depostion of $\mathrm{Cu}$ in the liver of sheep receiving orally large amounts of $\mathrm{Cu}$ and decreased liver $\mathrm{Cu}$ levels in sheep that were not given additional $\mathrm{Cu}$. In the latter sheep, $50 \mathrm{mg}$ ammonium tetrathiomolybdate given twice 'veekly did not produce histologically-detectable tissue damage even though liver and kidneys contained high levels of molybdenum. and kidneys contained elevated levels of $\mathrm{Cu}$.

4. It is concluded that chronic $\mathrm{Cu}$ poisoning can be successfully prevented or treated by intravenous injection of appropriate doses of ammonium tetrathiomolybdate.

Chronic copper poisoning is a well recognized hazard of sheep production (Underwood, 1977). There is evidence that the incidence of chronic $\mathrm{Cu}$ poisoning is increasing as more intensive methods of sheep production are adopted (Todd, 1972). The interaction between copper, molybdenum and sulphur in ruminants is well known (Dick et al. 1975) and several workers have used diets supplemented by Mo and sulphate to prevent or reduce the incidence of $\mathrm{Cu}$ toxicity in sheep (Ross, 1966; Hogan et al. 1968; Kline et al. 1971). The precise mechanism of interaction between these elements is not clearly understood, but the hypothesis outlined by Suttle (1974) and Dick et al. (1975) provides a plausible explanation. These workers believed that molybdate reacts with sulphide in the rumen to form thiomolybdate (TM) and this subsequently combines with dietary $\mathrm{Cu}$ or tissue $\mathrm{Cu}$ or both to form complexes in which $\mathrm{Cu}$ is unavailable. This raises the possibility that TM could be used to prevent or cure $\mathrm{Cu}$ toxicity. However, little is known of the effects of TM on animal tissues and information on the most effective route of administration is lacking.

The present study wass carried out to evaluate the response of $\mathrm{Cu}$-dosed and control sheep to intravenous administration of TM and to determine a safe dose of TM for the treatment and prevention of chronic $\mathrm{Cu}$ poisoning in sheep. Intravenous administration was chosen because the quantities of TM introduced into the animal could be carefully controlled and its effects on $\mathrm{Cu}$ metabolism would be more direct.

\section{MATERIALS AND METHODS \\ Experimental animals}

The results presented in this paper were collected from two experiments. All sheep were housed in individual pers, given water ad lib. and given $0.5 \mathrm{~kg}$ /animal per $\mathrm{d}$ of a proprietary sheep feed (Wesfeeds al lib. stud ram meal) which was reported to contain $0 \cdot 1,0 \cdot 7,9,40$ and $200 \mu \mathrm{g} / \mathrm{g}$ dry matte:r (DM) respectively of selenium, Mo, Cu, zinc and iron. All sheep were given two injections of Selvite E (Ilium Laboratories, New South Wales; contains $69 \mathrm{mg} / \mathrm{ml}$ vitamin $\mathrm{E}$ an $15 \mathrm{mg} \mathrm{Se} / \mathrm{ml}$ ), 1 week apart, the last being given 1 week before the commencement of the experiments. Test sheep in both experiments were dosed with an 
aqueous solution of $\mathrm{CuSO}_{4} \cdot 5 \mathrm{H}_{2} \mathrm{O}(2 \mathrm{~g} / \mathrm{l})$ on $5 \mathrm{~d}$ of the week at the rate $10 \mathrm{ml} / \mathrm{kg}$ body-weight. They were weighed, and bled before the start of the experiment to obtain predosing values in plasma of sorbitol dehydrogenase $(E C 1.1$.1 14; SD), creatine kinase (EC 2.7.3.2; CK) and blood urea nitrogen (BUN).

\section{Expt 1}

Eight, 6-9-month-old Merino sheep were divided into two groups A and B, with four animals in each. All sheep were dosed with $\mathrm{CuSO}_{4}$ solution. Sheep in Group A received TM injections twice weekly starting on the day on which the second rise of SD was detected this being an indication that haemolysis would soon occur. (Gooneratne, 1979). Dosing with $\mathrm{Cu}$ and administration of TM injections continued until the sheep were killed. In Group $\mathrm{B}$ the dosing with $\mathrm{CuSO}_{4}$ solution was discontinued once the haemolytic crisis occurred. These sheep received their first TM injection on the first day of haemolysis, then twice weekly until they died or were killed. One animal died before TM could be given. Details of the animals given TM are shown in Table 1.

\section{Expt 2}

A total of eighteen, 9-12-month-old Merino sheep were used in this experiment. They were divided into four groups, the animals in groups 1 and 2 being divided into four sub-groups $1 \mathrm{~A}$ and $1 \mathrm{~B}$ and $2 \mathrm{~A}$ and $2 \mathrm{~B}$ (see Table 2 ).

Group 1. Cu dosing was stopped at haemolysis. These sheep did not receive TM. Two died at haemolysis (group 1A), one died 3 weeks after the onset of haemolysis and one sheep survived for a further 11 weeks. The latter two are referred to as group 1 B.

Group 2. $\mathrm{Cu}$ dosing was stopped at, and TM injections $(1 \mathrm{ml} / \mathrm{dose})$ started, on the first day of haemolysis and continued twice weekly until the animals died or were killed. Of the six sheep in the group, two died after each had received one injection of TM and are referred to as group $2 \mathrm{~A}$. The remaining animals constitute group $2 \mathrm{~B}$.

Group 3. All sheep were dosed with $\mathrm{CuSO}_{4}$ solution until they were killed. TM injections $(2 \mathrm{ml} /$ dose) were begun at the second rise of SD activity and continued twice weekly until the animals were killed.

Group 4. This group was the control group. These animals were not dosed with $\mathrm{CuSO}_{4}$ solution but received TM injections $(1 \mathrm{ml} /$ dose) twice weekly commencing at varying times from the start of the experiment.

\section{Collection of blood}

Blood samples were collected from the jugular vein of all sheep 2 weeks before and at the start of the experiments, then twice weekly until the SD activity in the plasma of all sheep in group A of Expt 1 and in group 3 of Expt 2 had increased for the second time, and thereafter at weekly intervals until the animals died or were killed. At the haemolytic crisis blood was collected more frequently.

\section{Analytical techniques}

$S D$. SD activity was measured in the plasma of all sheep in both experiments as described by Ford (1967).

$\mathrm{Cu}, \mathrm{Zn}$ and $\mathrm{Fe}$ in tissues. $\mathrm{Cu}$ and $\mathrm{Fe}$ analyses were performed on liver and kidney of sheep in both experiments, and on spleen and left ventricle of sheep in Expt 1. Zn estimations were carried out on liver and kidney of sheep in Expt 2. The tissues were digested in concentrated nitric, sulphuric and perchloric acids (Ishmael et al. 1972) and $\mathrm{Cu}, \mathrm{Zn}$ and $\mathrm{Fe}$ levels measured on an atomic absorption spectrophotometer (Varian Techtron, Model 1200). 
Mo in tissues. Mo was estimated by a modification of the method described by Norheim \& Waasjo (1977) on the liver and kidney of all sheep in Expt 2.

Preparation of TM. TM was prepared by bubbling hydrogen sulphide gas through a solution of ammonium molybdate as described by Tridot \& Bernard (1962). Crystals of TM harvested were dissclved in sterile saline ( $9 \mathrm{~g}$ sodium chloride/l) as a $50 \mathrm{mg} / \mathrm{ml}$ solution and stored as 5 or $10 \mathrm{~m} . \mathrm{l}$ portions in stoppered sterile vials at $-20^{\circ}$. When required, the solutions were thawed at room temperature, centrifuged and the supernatant fraction was used for intravenous administration. Tetrathiomolybdate was identified as the predominant component from the absorption spectra (Aymonino et al. 1969) with peaks at 241, 316 and $463 \mathrm{~nm}$. After storing the TM for the duration of the experiment (4.5 months) there was no change in the absorption spectrum other than a decrease of approximately $3 \%$ in the molar extinction.

Histology. Sections for light microscopy were prepared from liver, kidney, spleen and femur. These tissues were fixed in buffered formal saline, embedded in paraffin wax and $5 \mu \mathrm{m}$ sections stained by haematoxylin and eosin. Liver and kidney sections were stained by the periodic acid Schiff (PAS) method with and without diastase (EC 3.2.1.1), and by the rubeanic acid and 5-p-climethylaminobenzylidine rhodanine (DMABR) methods for $\mathrm{Cu}$. Kidney sections were also stained with Perls' Prussian blue method for Fe.

\section{RESULTS \\ Clinical Findings}

The details of individual sheep are given in Tables 1 and 2.

\section{$\operatorname{Expt} 1$}

Sheep in group A received three dosages of TM (Table 1) for varying periods of time and were killed at different intervals of time to assess the sequence of changes occurring in a variety of tissues. None of the sheep in group A had a haemolytic crisis and were killed after all the sheep in group B went into haemolysis. All sheep in group A except no. 214 remained clinically norraal throughout the experiment. Sheep no. 214 became anorexic after receiving the second injection of the higher dose $(4 \mathrm{ml})$ of TM, passed soft faeces, had pale conjunctiva but was nct jaundiced. This animal was killed in extremis.

Abnormalities were not seen in any of the sheep in group B before the onset of haemolysis. Signs of haemolysis were similar to those previously reported (Todd, 1962). One animal died at haemolysis before receiving its first TM injection and will not be considered further here. Of the remaining three sheep, two which received $2 \mathrm{ml}$ doses of TM, developed watery diarrhoea after two injections. The diarrhoea persisted, one sheep died and the other was killed in extremis. The only animal to survive in this group received $1 \mathrm{ml}$ dose of TM, did not develop diarrhoea and was killed after four injections of TM.

\section{Expt 2}

The sheep in this experiment did not develop diarrhoea. Sheep in groups 3 and 4 did not show any clinical abnormality throughout the course of the experiment. Abnormalities were not seen in any of the sheep in other groups before the onset of haemolysis. The signs seen at haemolysis were similar to those seen in Expt 1. Loss in body-weight occurred in sheep in groups $1 \mathrm{~A}$ and $2 \mathrm{~A}$ that died at haemolysis, while animals in groups 3 and 4 increased in body-weight. Of the six sheep given TM at haemolysis (group 2), two died after one injection and the remaining four survived from 77-79 $\mathrm{d}$ following haemolysis when they were killed in good health. This result should be compared with a mortality of three of four sheep not given TM at haemolysis (group 1). 


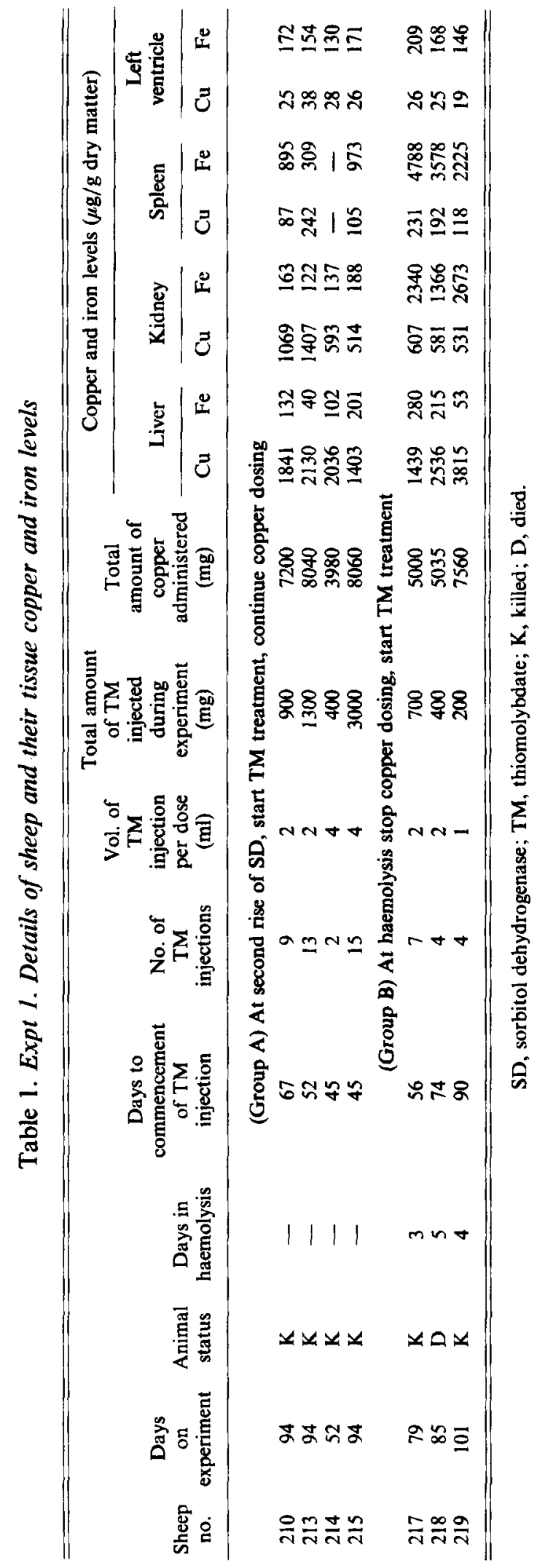




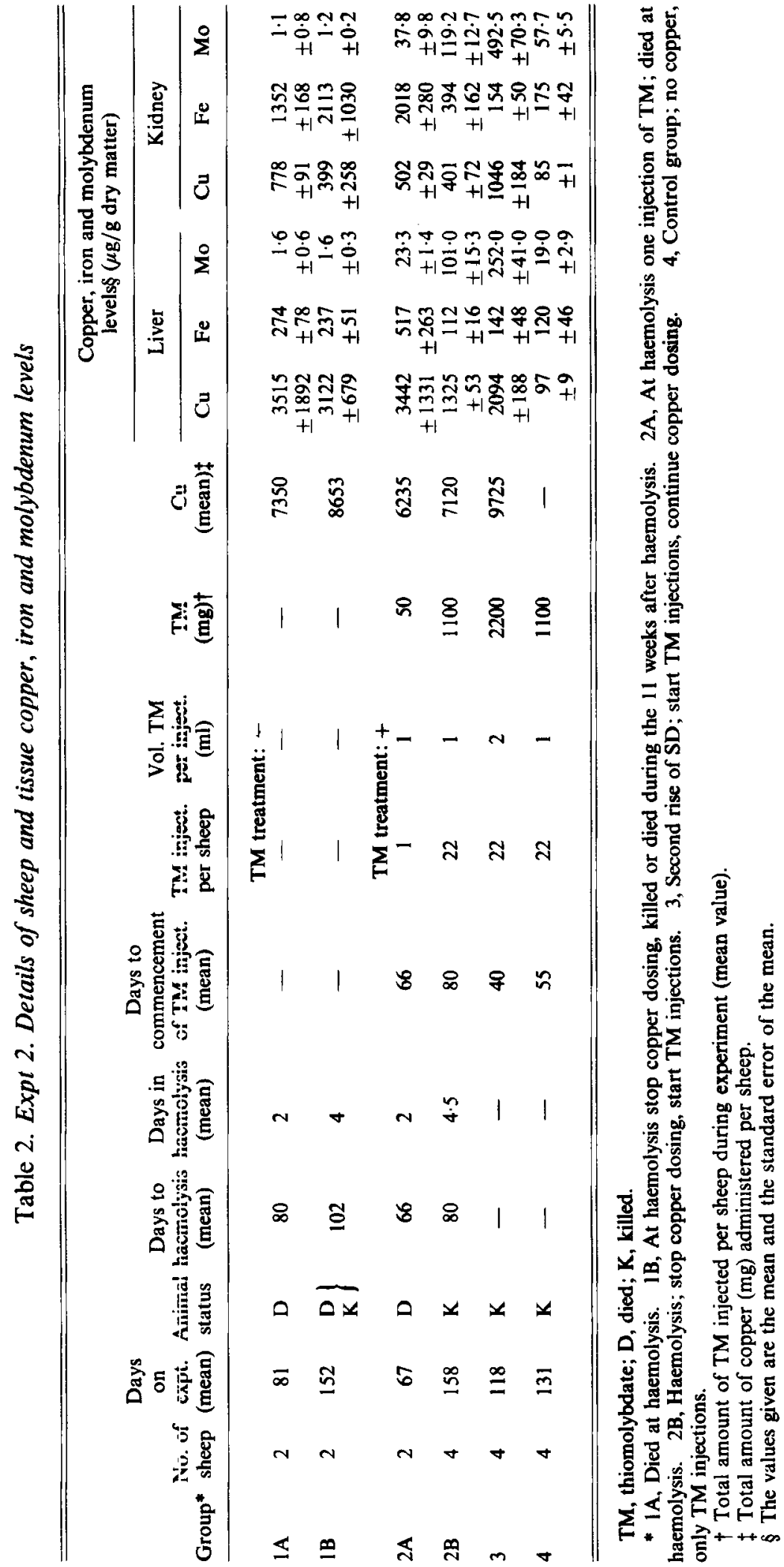




\section{Postmortem findings \\ Expt I}

Abnormalities were not seen in any of the sheep in group A except for sheep no. 214 which was killed in extremis. The liver of this animal was swollen and bronze coloured and its kidneys were swollen and had petechial haemorrhages. Of the sheep in group B, abnormalities were not seen in organs of sheep no. 219 but sheep nos. 217 and 218 were severely dehydrated, had pale, swollen livers and dark swollen kidneys, changes that are typical of chronic $\mathrm{Cu}$ poisoning (Gopinath \& Howell, 1975).

\section{Expt 2}

Groups $I A$ and $2 A$. The changes seen in these animals were typical of those seen in sheep that were killed or had died during the haemolytic crisis of chronic $\mathrm{Cu}$ poisoning (Gopinath \& Howell, 1975).

Group $1 B$. The livers of sheep in this group were dark yellow in colour. This was most marked in one sheep which also had mottled, greyish black kidneys and pneumonic lungs.

Group $2 B$. The livers of these animals were darker than normal. This was most marked in two sheep which also had very dark brown kidneys.

Group 3. The livers were of normal colour but were friable and the kidneys were blackish brown in colour.

Group 4. Gross abnormalities were not seen in livers and kidneys of sheep in this group.

\section{Histology \\ Expt 1. Liver and kidney}

Group A. Numerous large pigmented Kupffer cells were scattered throughout the lobules. They were PAS positive and stained for $\mathrm{Cu}$ with rubeanic acid and DMABR. The cells around the central vein were not necrotic but a few necrotic hepatocytes were present within some lobules. Kidneys showed a marked increase in brown or eosinophilic granules within the cytoplasm of tubule cells. These granules did not stain positively for Fe but some of them gave a positive reaction with the $\mathrm{Cu}$ stains. The tubules of sheep nos. 214 and 215 were dilated.

Group $B$. The changes in the liver were similar to those in Group A. The kidney tubules of all sheep were dilated, contained casts and had heavily-pigmented deposits within them. This pigment gave a positive reaction for $\mathrm{Fe}$ with Perls' stain but did not stain for $\mathrm{Cu}$.

\section{Expt 1. Spleen}

Significant alterations were not observed except for the presence of brown, Fe containing, pigmented macrophages in sheep of Group B.

\section{Expt 2. Liver}

The changes seen in livers of sheep in groups $1 \mathrm{~A}$ and $2 \mathrm{~A}$ were typical of those seen in sheep at the time of the haemolytic crisis of chronic $\mathrm{Cu}$ poisoning in that numerous large pigmented Kupffer cells were present and many centrilobular parenchymal cells were necrotic (Gopinath \& Howell, 1975).

The livers of the two sheep in group 1B contained numerous large pigmented $\mathrm{Cu}$ containing Kupffer cells and some necrotic parenchymal cells. The changes were similar to those reported in animals killed in the post-haemolytic phase of chronic $\mathrm{Cu}$ poisoning (Gopinath \& Howell, 1975). The livers of sheep in group 2B showed little evidence of damage. Centrilobular necrosis was absent but a few isolated necrotic parenchymal cells were seen, and small numbers of large Kupffer cells with reddish or yellow cytoplasm which stained for $\mathrm{Cu}$ were found scattered throughout the lobule. 
Livers of group 3 sheep were similar to those seen in group 2B except that fewer necrotic cells were found within the lobules.

Changes within the livers of group 4 sheep were minimal, the only change observed was the presence of a small number of large Kupffer cells with red or brown cytoplasm.

\section{Kidney}

The changes observed in the kidneys of sheep in groups $1 \mathrm{~A}$ and $2 \mathrm{~A}$ were typical of those seen in sheep that died or were killed during the haemolytic crisis (Gopinath et al. 1974), in that there was extensive necrosis and degeneration of tubule cells. Many tubule cells contained pigment granules which were positive for Fe. The changes seen in group IB sheep were similar but necrosis was not widespread. The histological appearance of the kidneys of sheep in groups $2 \mathrm{~B}$ and 3 was similar in that little damage was evident. Some tubule cells contained cytoplasmic granules which gave a positive reaction for $\mathrm{Cu}$. Changes in the kidneys of sheep in group 4 were minimal.

\section{Femur}

The femurs of sheep in groups 1A, 1B, 2A and of two sheep in group 3 showed little activity in the endochondral plate much of which was sealed off. In the remaining sheep the endochondral plate was still active.

\section{Tissue $\mathrm{Cu}$ levels}

Expt. 1. The Cu levels in liver, kidney, left ventricle and spleen of individual sheep together with the total amount of $\mathrm{Cu}$ and TM administered to each sheep is given in Table 1 . In group A, although sheep nos. 213 and 215 were dosed with approximately the same amount of $\mathrm{Cu}$, sheep no. 215 received more TM and had a much lower $\mathrm{Cu}$ level in its liver. A similar pattern was observed between sheep nos. 217 and 218 of group B. The kidneys of all sheep had high $\mathrm{Cu}$ levels.

Expt 2. The $\mathrm{Cu}$ levels in liver and kidney of all sheep are given in Table 2. Liver $\mathrm{Cu}$ levels of sheep in groups $1 \mathrm{~A}, 1 \mathrm{~B}$ and $2 \mathrm{~A}$ were markedly increased when compared with the levels of those sheep in other groups which received more than one TM injection. Even though all sheep in group 3 were dosed with $\mathrm{Cu}$ for more than $110 \mathrm{~d}$ and hence received the highest amount of $\mathrm{Cu}$, the amount of $\mathrm{Cu}$ stored in their livers was much less than that found in the livers of sheep in groups $1 \mathrm{~A}$ and $2 \mathrm{~A}$ which were dosed only for 80 and $66 \mathrm{~d}$ respectively. However, the kidneys of sheep in group 3 accumulated large amounts of $\mathrm{Cu}$. The sheep in group 4 had low liver $\mathrm{Cu}$ levels but the $\mathrm{Cu}$ levels in their kidneys was more than would be found in the kidneys of normal sheep $15.55 \pm 0.96$ (Gopinath et al. 1974); 15.05 \pm 0.38 (Gooneratne, 1979).

\section{Tissue $\mathrm{Zn}$ and $\mathrm{Fe}$ Levels}

Expt 1. Iron levels in liver and left ventricle of all sheep and spleen and kidneys of sheep in group A were within the normal range (Table 1), but the spleen and kidneys of sheep in group B had markedly elevated Fe levels.

Expt 2. The sheep in groups 1A and 2A that died at haemolysis, and those in group IB that had haemolytic srisis but did not receive $T M$, had markedly elevated $\mathrm{Zn}$ $(265.8 \pm 49.4 \mu \mathrm{g} / \mathrm{g}$ liver $\mathrm{DM})$ and Fe levels in their livers and increased Fe levels in their kidneys. Values for $\mathrm{Fe}$ are given in Table 2. Zinc (120.7 $\pm 5.4 \mu \mathrm{g} / \mathrm{g}$ liver DM) and $\mathrm{Fe}$ levels were low in livers of sheep, which received TM and survived (groups $2 \mathrm{~B}, 3$ and 4 ). $\mathrm{Zn}$ levels in the kidneys of these th ree groups of sheep were variable $(115.4 \pm 5 \cdot 8 \mu \mathrm{g} / \mathrm{g}$ kidney DM) but the Fe levels were low. 


\section{Tissue Mo levels}

Mean levels of Mo in liver and kidneys of all groups of sheep of Expt 2 are given in Table 2. The sheep in groups $1 \mathrm{~A}$ and $1 \mathrm{~B}$ which did not receive TM had low Mo levels in their livers and kidneys. The mean Mo levels in the livers and kidneys of two sheep in group $2 \mathrm{~A}$ were 23 and $38 \mu \mathrm{g} / \mathrm{g}$ DM respectively after one injection of TM. Sheep in groups $2 \mathrm{~B}$ and 3 had high Mo levels in both liver and kidney and this was most marked in sheep of group 3 which received $\mathrm{Cu}$ continuously along with TM injections. Although the sheep in group 4 received the same dose of TM as those in group $2 B$, the Mo levels in the liver and kidneys of the sheep in group 4 were much lower.

\section{$S D$ activity}

All sheep dosed with $\mathrm{CuSO}_{4}$ solution had high levels of SD activity in plasma before haemolysis, including those that received TM in addition to $\mathrm{Cu}$ (group $\mathrm{A}$, Expt 1; group 3, Expt 2). Peaks of SD activity were not observed in any animal after the cessation of haemolysis and at no time was SD activity elevated in animals given TM but not $\mathrm{Cu}$ (group 4, Expt 2).

\section{DISCUSSION}

Dietary supplements of $\mathrm{Mo}$ and $\mathrm{SO}_{4}$ have previously been used in attempts to prevent the occurrence of chronic $\mathrm{Cu}$ poisoning in sheep (Ross, 1966; Hogan et al. 1968; Kline et al. 1971; Suttle, 1979). The results presented here show for the first time that chronic $\mathrm{Cu}$ poisoning can be prevented by the intravenous administration of TM, a compound that contains Mo and S, and that has been postulated to form in the rumen of sheep fed supplements of $\mathrm{Mo}$ and $\mathrm{SO}_{4}$ (Dick et al. 1975).

The main aim of Expt 1 was to determine the amounts of TM to be used in sheep of different $\mathrm{Cu}$ status. It was found that dose rates of $100 \mathrm{mg}$ TM twice weekly, or $50 \mathrm{mg}$ TM twice weekly were safe for animals receiving $\mathrm{Cu}$ or not receiving $\mathrm{Cu}$, respectively. When these doses were increased diarrhoea occurred. Molybdenum-containing supplements have been previously observed to cause diarrhoea in ruminants (Allcroft \& Lewis, 1956; Ward, 1978) and Fell et al. (1979) reported lesions in the enterocytes of rats given TM. The mechanism of these effects is still uncertain. Some workers have noted that Mo is largely excreted in the faeces of ruminants (Bell et al. 1964; Miller et al. 1972) and that it may disturb bacterial activity in the large intestine and thereby cause diarrhoea (Underwood, 1976). Others have postulated that because molybdate depresses liver sulphide oxidase (EC 1.8 .3 .1 ) activity, the diarrhoea may result from a failure to oxidize highly toxic endogenous sulphide.

Oral $\mathrm{Cu}$ supplements can prevent the diarrhoea caused by Mo (Brouwer et al. 1938; Ferguson et al. 1938, 1943). Thus, in our experiments animals receiving $\mathrm{Cu}$ were able to tolerate twice the TM dose of animals not receiving oral $\mathrm{Cu}$. It appears that even when TM is given intravenously it exerts an effect on the alimentary canal possibly because it is excreted into the gut contents. The prevention of diarrhoea by dietary $\mathrm{Cu}$ under these circumstances is consistent with the hypothesis of Dick et al. (1975) in which TM combines with $\mathrm{Cu}$ in the gut to form an insoluble and therefore non-toxic compound.

The intravenous injections of TM decreased the concentration of $\mathrm{Cu}$ in the liver (Table 2). Thus, TM at a dose rate of $50 \mathrm{mg}$ twice weekly for 11 weeks caused a decrease of $1797 \mu \mathrm{g}$ $\mathrm{Cu} / \mathrm{g}$ liver (3122-1325 $\mu \mathrm{g})$ a decrease of approximately $58 \%$ of the liver copper. Expressed in another way, $1 \mathrm{mg}$ atom Mo caused a decrease of about $0.5 \mathrm{mg}$ atom $\mathrm{Cu}$ from the liver. (This calculation is based on average liver dry weight of $121 \mathrm{~g}$ ). Similarly, TM injections reduced liver $\mathrm{Cu}$ levels in animals not receiving supplemental $\mathrm{Cu}$ (Expt 2, group 4). In these 
animals the liver Cu concentration was $96 \mu \mathrm{g} / \mathrm{g}$, compared with levels of $258 \mu \mathrm{g} / \mathrm{g}$ in normal sheep on a similar diet (Gooneratne et al. 1979). The sheep given this treatment may have been marginally $\mathrm{Cu}$ deficient, since caeruloplasmin oxidase activity was beginning to decrease in the later stages of the experiment (Gooneratne, 1979).

According to Suttle (1979) TM given in the food to postweaned sheep reduces only the absorbability of $\mathrm{Cu}$ from the gut and does not greatly accelerate the removal of $\mathrm{Cu}$ already accumulated in the liver, but the levels of TM fed in that experiment were low $(3 \mathrm{mg} \mathrm{Mo} / \mathrm{kg}$ DM of pelleted food) and it is possible that all the TM complexed with $\mathrm{Cu}$ within the gut, leaving none to complex with the $\mathrm{Cu}$ in the liver. The decrease in liver $\mathrm{Cu}$ in the present experiment occurred even in the presence of a high level of plasma $\mathrm{Cu}$ and with a direct-reacting $\mathrm{Cu}$ level that increased with each TM injection (Gooneratne et al. 1981).

As expected, the Mo levels in liver and kidney of sheep injected with TM were high. In Expt 2 the sheep in groups 2B and 4 were injected with the same amount of TM but the liver Mo levels of group 2B sheep were more than five times and their kidney levels more than twice, the levels of sheep in group 4. Sheep in group 3 which received the higher doses of TM $(2 \mathrm{ml})$, had liver Mo levels which were no more than twice those found in livers of sheep in group 2B while tie kidneys contained more than four times the Mo levels found in kidneys of sheep in group 2B. Thus it appears that the deposition of Mo in liver and kidney depends on the availability of $\mathrm{Cu}$ within the body. Availability of $\mathrm{Cu}$ could be exogenous as in group 3 or endogenous as in sheep of group $2 \mathrm{~B}$ which had stored $\mathrm{Cu}$ in their liver before the start of TM injections. It is possible that Mo present in these organs was being deposited as a $\mathrm{Cu}-\mathrm{Mo}$ complex. Similar observation on the accumulation of $\mathrm{Cu}$ in the kidneys of Mo-supslemented sheep have been reported by Smith et al. (1968) and Marcilese et al. (1970). Bremner \& Young (1978) reported that $\mathrm{Cu}$ and $\mathrm{Mo}$ accumulated together in the kidneys of $\mathrm{Mo}$ and $\mathrm{SO}_{4}$ fed sheep in the ratio of about $2: 1$. This was clearly not so in the present experiment where much higher levels of Mo and $S$ were injected as TM.

The presence of increased $\mathrm{Zn}$ and Fe levels in livers containing high $\mathrm{Cu}$ levels are similar to our previous findings (Ciooneratne et al. 1979). Sheep which died at haemolysis had large amounts of $\mathrm{Fe}$ in their lidneys. This is probably due to increased amounts of $\mathrm{Fe}$, as breakdown products of erythrocytes being deposited in the kidneys. The presence of large amounts of $\mathrm{Fe}$ in the spleens of sheep that had undergone a haemolytic crisis (group B of Expt 1) was probably due to the phagocytosis of the breakdown products of damaged erythrocytes by the reticulo-endothelial system (Schalm et al. 1975). It was interesting to find comparatively low Fe: levels in the kidneys of sheep given TM and possibly TM may have been responsible for its removal. This property of TM could yet be another factor responsible for the rapid recovery from haemolysis and the small amount of kidney damage found in treated sheep.

The administration of TM did not appear to produce histologically-detectable damage to liver or kidney even though both tissues contained high levels of Mo and the kidneys contained more than the normal amounts of $\mathrm{Cu}$. These animals increased in weight throughout the course of the experiment. Although high SD levels were observed in the plasma of sheep in group 4 of Expt 1 and in group 3 of Expt 2 there was little histological evidence of liver damage. There was also little evidence of morphological or functional kidney damage despite the high level of $\mathrm{Cu}$ present. This result confirms the findings of Gopinath et al. (1974) who were of the opinion that both hypercupraemia and haemolysis were required to produce the kidney damage seen in chronic $\mathrm{Cu}$ poisoning. These results indicate that TM prolonged the pre-haemolytic phase of chronic $\mathrm{Cu}$ poisoning, prevented the development of extensive centrilobular necrosis of the liver and the development of haemolytic anaemia. It is possible that lowering the excessive $\mathrm{Cu}$ deposition in the livers 
of sheep in group 3 of Expt 2, may have prevented damage to the liver and this may possibly have been a key factor in the prevention of haemolysis. The four sheep which were given TM at haemolysis and subsequently killed (group 2B of Expt 2) showed little evidence of centrilobular necrosis of liver or of kidney damage. Yet these animals had developed a haemolytic crisis. The tissue recovery was probably a direct result of TM treatment and is worthy of further investigation.

Although connective tissue changes in long bones of sheep grazing high-Mo pastures (Underwood, 1976) and skeletal abnormalities in rats given TM in the diet (Spence et al. 1980) have been reported, such changes were absent in the femurs of sheep given TM injections. The only change seen in the femurs was closure of the endochondral plate in sheep that developed a haemolytic crisis and which did not receive or were given a small amount of TM, and in two animals given TM at the second rise of SD.

It may be concluded from the present study that TM injections prevented: $(a)$ the occurrence of the haemolytic crisis when given to sheep before haemolysis and $(b)$ the occurrence of further 'haemolytic crises' and the development of significant tissue damage when given to sheep already in haemolysis. Gopinath \& Howell (1975) showed that cessation of $\mathrm{Cu}$ dosing alone does not necessarily lead to quick elimination of $\mathrm{Cu}$ from the tissues. They thought that persistently-elevated levels of $\mathrm{Cu}$ in liver parenchymal cells may affect the structure and function of the cells which may then contribute to further crises. Thus the metabolic role of TM in chronic $\mathrm{Cu}$ poisoning appears to be its ability to prevent excessive deposition of $\mathrm{Cu}$ in the liver of sheep receiving large amounts of $\mathrm{Cu}$ in the diet and its ability to decrease liver $\mathrm{Cu}$ levels in sheep receiving normal levels of $\mathrm{Cu}$ via the gut. Evalutation of the effects of TM on the histological features of liver, kidney and femur indicated that TM does not cause any undesirable structural defects or any harmful effects on the animal per se, if given in appropriate doses. The tolerated dose would vary and would depend on the $\mathrm{Cu}$ status of the animal and its daily intake of $\mathrm{Cu}$. The investigation of the use of this compound for the prevention and treatment of chronic $\mathrm{Cu}$ poisoning in sheep will be continued. Further results may suggest its use as an adjunct to penicillamine in the treatment of Wilson's disease in man where it may be of particular value as a short term treatment in cases presenting with haemolysis or with penicillamine associated immune mediated diseases.

The authors wish to thank Mr M. Gates for technical assistance. This work was supported by a grant from the Australian Research Grants Committee.

\section{REFERENCES}

Allcroft, R. \& Lewis, G. (1956). Landbouwk. Tijdschv 68, 711.

Aymonino, P. J., Ranade, A. C. \& Müller, A. (1969). Z. anorg. allg. Chem. 371, 295.

Bell, M. C., Diggs, B. G., Lowrey, R. S. \& Wright, P. L. (1964). J. Nutr. 84, 367.

Bremner, I. \& Young, B. W. (1978). Br. J. Nutr. 39, 325.

Brouwer, F., Frens, A. M., Reitsma, P. \& Kalesvaart, C. (1938). Versl. landbouwk. Onderz. $44 c, 267$.

Dick, A. T., Dewey, D. W. \& Gawthorne, J. M. (1975). J. agric. Sci., Camb. 85, 567.

Fell, B. F., Dinsdale, D. \& El-Gallad, T. (1979). J. Comp. Path. Ther. 89, 495.

Ferguson, W. S., Lewis, A. H. \& Watson, S. J. (1938). Nature, Lond. 141, 553.

Ferguson, W. S., Lewis, A. H. \& Watson, S. J. (1943). J. agric. Sci., Camb. 33, 44.

Ford, E. J. H. (1967). J. Comp. Path. Ther. 77, 405.

Gooneratne, S. R. (1979). Morphometric, electron microscopic, biochemical and pathological investigation of liver of normal and copper poisoned sheep. PhD Thesis, Murdoch University, Western Australia.

Gooneratne, S. R., Howell, J. McC. \& Gawthorne, J. M. (1979). Res. vet. Sci. 27, 30.

Gooneratne, S. R., Howell, J. McC. \& Gawthorne, J. M. (1981). Br. J. Nutr. 46, 469.

Gopinath, C., Hall, G. A. \& Howell, J. McC. (1974). Res. vet. Sci. 16, 57.

Gopinath, C. \& Howell, J. McC. (1975). Res. vet. Sci. 19, 35.

Hogan, K. G., Money, D. F. L. \& Blayney, A. (1968). N.Z. Jl agric. Res. 11, 435.

Ishmael, J., Gopinath, C. \& Howell, J. McC. (1972). Res. vet. Sci. 13, 22. 
Kline, R. D., Hays, V. W. \& Cromwell, G. L. (1971). J. Anim. Sci. 33, 771.

Marcilese, N. A., Ammerman, C. B., Valsecchi, R. M., Dunavant, B. F. \& Davis, G. K. (1970). J. Nutr. $100,1399$. Miller, J. K., Moss, B. R., Bell, M. C. \& Snead, N. N. (1972). J. Anim. Sci. 34, 846.

Norheim, G. \& Waasjo, E. (1977). Z. Analyt. Chem. 286, 229.

Ross, D. B. (1966). Br. vet. J. 1'!2, 279.

Schalm, O. W., Jain, N. C. \& Carroll, E. J. (1975). Veterinary Haematology, 3rd edn, p. 76. Philadelphia: Lea and Fabiger.

Smith, B. S. W., Field, A. C. \& Suttle, N. F. (1968), J. Comp. Path. Ther. 78, 449.

Spence, J. A., Suttle, N. F., Werham, G., El-Gallad, T. \& Bremner, I. (1980). J. Comp. Path. Ther. 90, 139.

Suttle, N. F. (1974). Proc. Nutr. Soc. 33, 299.

Suttle, N. F. (1979). Proc. Nutr. Soc. 38, 58A.

Todd, J. R. (1962). Vet. Bull. 32, 573.

Todd, J. R. (1972). J. agric. Sci., Camb. 79, 191.

Tridot, G. \& Bernard, J. C. (1962). Acta Chim. hung. 34, 179.

Underwood, E. J. (1976). In The Proceedings of the International Symposium on Molybdenum in the Environment, vol. 1, p. 9 [W. R. Chappell and K. K. Peterson, editors]. New York and Basel: Marcel and Dekker Inc.

Underwood, E. J. (1977). Trace Elements in Human and Animal Nutrition, 4th edn. p. 95. New York, San Francisco and London: Academic Press.

Ward, G. M. (1978). J. Anim. Sci. 46, 1078. 